\title{
KARANG TARUNA ENTREPRENEURSHIP TRAINING IN PURWADANA VILLAGE, KARAWANG REGENCY PELATIHAN KEWIRAUSAHAAN KARANG TARUNA DESA PURWADANA KABUPATEN KARAWANG
}

\author{
Citra Savitri \\ citra.savitri@ubpkarawang.ac.id
}

\begin{abstract}
The implementation of community service activities aims to increase public knowledge and interest in entrepreneurship. The community service method used is lecture and discussion. The material includes theories about how to find business opportunities in an effort to improve the economy as well as possible. Participants were given an understanding regarding the importance of reading business opportunities in the hope that MSME businesses could develop well with capital provided through BMT. The results obtained from this activity, all participants stated that this activity was very useful to increase knowledge and insight on how to utilize each business opportunity through capital assistance from $B M T$.
\end{abstract}

Keyword: Business Opportunities, BMT

\begin{abstract}
Abstrak: Penyelenggaraan kegiatan pengabdian kepada masyarakat ini bertujuan meningkatkan pengetahuan dan minat masyarakat dalam berwirausaha. Metode pengabdian kepada masyarakat yang digunakan adalah ceramah dan diskusi Materi mencakup teori tentang bagaimana menemukan peluang bisnis usaha dalam upaya meningkatkan perekonomian dengan sebaik mungkin. Peserta diberikan pemahaman terkait pentingnya membaca peluang bisnis dengan harapan agar usaha UMKM bisa berkembang dengan baik dengan modal yang diberikan lewat BMT. Hasil yang diperoleh dari kegiatan ini, seluruh peserta menyatakan kegiatan ini sangat bermanfaat dapat menambah pengetahuan dan wawasan bagaimana cara memanfaatkan setiap peluang bisnis lewat bantuan modal dari BMT.
\end{abstract}

Kata kunci: Peluang Bisnis, BMT.

\section{PENDAHULUAN}

Kewirausahaan dapat mendukung kesejahteraan masyarakat serta memberikan banyak pilihan barang dan jasa bagi konsumen, baik dalam 
maupun lua $\mathrm{r}$ negeri.Meskipun perusahaanraksasa lebih menarik perhatian publik dan seri ng kali menghiasi berita utama, bisnis kecil tidak kalah penting perannya bagi kehidupan sosial dan pertumbuhan ekonomi suatu Negara. Wirausahawan merupakan kelompok yang menggerakkan perekonomian masyarakat" dan "menjelaskan bahwa perkembangan ekonomi menuntut adanya suatu perilaku wirausaha" Maka dari itu peran dari wirausaha atau entrepreneurship sangatlah penting dalam membantu menyediakan lapangan kerja, menumbuh kembangkan perekonomian negara. Betapa pentingnya kewirausahaan bagi pertumbuhan ekonomi, saat ini pemerintah berupaya dengan berbagai cara untuk menfasilitasi bertumbuh kembangnya entrepreneurship diantaranya dengan adanya pendidikan entrepreneurship education yang terus dikembangkan di perguruan tinggi dan berbagai lembaga pendidikan baik formal maupun informal melalui program dan pembinaan kewirausahaan tentang mengajarkan bagaimana mengelola suatu usaha serta memotivasi agar setelah lulus ataupun masih dalam masa studi mereka berani memutuskan untuk berwirausaha dan ini merupakan tanggung jawab bagi lembaga pendidikan untuk mendidik dan memberikan motivasi guna mencetak young entrepreneurs (wirausahawan muda) yang berguna di masa depan dalam membantu menumbuhkan perekonomian negara.

Entrepreneurship atau kewirausahaan tidak lepas dari usaha mikro, kecil, dan menengah. Pada dasarnya suatu usaha baru yang dibentuk seorang entrepreneur dapat berupa usaha mikro, kecil, atau menengah. Usaha Mikro adalah usaha produktif milik orang perorangan atau badan usaha perorangan yang memenuhi kriteria Usaha Mikro atau memiliki kekayaan bersih paling banyak Rp.50.000.000,00 (lima puluh juta rupiah) atau memiliki hasil penjualan tahunan paling banyak Rp.300.000.000,00 (tiga ratus juta rupiah). Usaha kecil adalah usaha ekonomi produktif yang berdiri sendiri yang dilakukan oleh orang perorangan atau badan usaha yang bukan merupakan anak perusahaan atau bukan cabang perusahaan yang dimiliki, dikuasai, atau menjadi bagian baik langsung maupun tidak langsung dari Usaha Menengah atau Usaha Besar yang memenuhi criteria Usaha Kecil memiliki kekayaan bersih lebih dari Rp.50.000.000,00 (lima puluh juta rupiah) sampai dengan paling banyak Rp.500.000.000,00 (lima ratus 
juta rupiah) atau memiliki hasil penjualan tahunan lebih dari Rp.300.000.000,00 (tiga ratus juta rupiah) sampai dengan paling banyak Rp.2.500.000.000,00 (dua miliar lima ratus juta rupiah).

Usaha menengah adalah usaha ekonomi produktif yang berdiri sendiri, yang dilakukan oleh orang perorangan atau badan usaha yang bukan merupakan anak perusahaan atau cabang perusahaan yang dimiliki, dikuasai, atau menjadi bagian baik langsung maupun tidak langsung dengan usaha dengan Usaha Kecil atau Usaha Besar dengan jumlah kekayaan bersih atau hasil penjualan tahunan memiliki kekayaan bersih lebih dari Rp500.000.000,00 (lima ratus juta rupiah) sampai dengan Rp.10.000.000.000,00 (sepuluh miliar rupiah) atau memiliki hasil penjualan tahunan lebih dari Rp.2.500.000.000,00 (dua miliar lima ratus juta rupiah) sampai dengan paling banyak Rp.50.000.000.000,00 (lima puluh miliar rupiah). Sehubungan dengan hal tersebut, maka dipandang perlu untuk memberikan wawasan peningnya berwirausaha kepada masyarakat dan bagaimana mengelola UMKM tersebut atas dasar prinsip manajemen. Prinsip manajamen meliputi pengelolaan sumber daya manusia, pengelolaan keuangan dan laporan keuangan, pengelolaan bidang produksi, dan pengelolaan pemasaran produk UMKM. Disamping itu, pelatihan ini juga mengajarkan bagaiman untuk bisa bertahan kewirausahaan dalam menghadapi persaingan lokal ataupun global.

Desa Purwadana adalah salah satu desa yang ada di Kabupaten Karawang yang dikepalai oleh seorang kepada desa dan dibantu oleh seorang sekretaris desa dan segenap perangkat desa. Kondisi mata pencaharian masyarakat di wilayah Desa Purwadana bekerja sebagai buruh tani (sebagian besar), peternak, pedagang, pengusaha home industry, karyawan swasta dan PNS. Menurut PERMENSOS tahun 2010 bahwa Karang Taruna adalah organisasi sosial kemasyarakatan sebagai wadah dan sarana pengembangan setiap anggota masyarakat yang tumbuh dan berkembang atas dasar kesadaran dan tanggungjawab sosial dari, oleh dan untuk masyarakat terutama generasi muda di wilayah desa/kelurahan terutama bergerak dibidang usaha kesejahteraan sosial. Keberadaan karang taruna yang mayoritas berisi generasi muda yang produktif sangat diperlukan di tengah-tengah masyarakat sebagai penggerak dan agen perubahan dalam rangka pencapaian tujuan bersama 
yaitu kesejahteraan masyarakat. Salah satu upaya pencapaian kesejahteraan adalah dengan memperbaiki tingkat perekonomian masyarakat setempat. Oleh karena itu, dibutuhkan pembekalan dan pelatihan yang mendukung upaya tersebut seperti pelatihan motivasi berwirausaha, kewirausahaan, manajemen bisnis, koperasi, dan lain-lain. Dengan pelatihan- pelatihan semacam itu diharapkan semangat dan motivasi anggota karang taruna dapat terpacu sehingga akan muncul unit-unit bisnis/usaha yang baru dan dapat memberdayakan masyarakat setempat yang pada akhirnya akan meningkatkan tingkat perekonomian masyarakat.

Disisi lain, lembaga Pendidikan Tinggi/Universitas harus selalu menjunjung tinggi dan melaksanakan Tri Dharma Perguruan Tinggi yang salah satunya adalah pengabdian pada masyarakat. Oleh karena itu, dalam rangka pengabdian pada masyarakat dan mempertimbangkan pentingnya pembekalan dan pelatihan mengenai kewirausahaan kepada karang taruna sebagai penggerak masyarakat, Program Studi Manajemen Universitas Buana Perjuangan Karawang mengadakan pelatihan wirausaha bagi salah satu karang taruna yang berada di wilayah Kab. Karawang yaitu Karang Taruna Desa Purwadana Kabupaten Karawang.

Pengertian Kewirausahaan menurut Hisrich-Peters (H. Buchari Alma, 2004: 26), Entrepreneur is the process of creating something different with value by devoting the necessary time and effort, assuming the accompanying financial, psychic, and social risks, and receiving the resulting rewards of monetary and personal satisfaction and independence. Artinya kewirausahaan adalah proses menciptakan sesuatu yang lain dengan menggunakan waktu dan kegiatan disertai modal dan resiko serta menerima balas jasa dan kepuasan serta kebebasan pribadi. Sedangkan menurut Dr. Kasmir, M.M, (2014: 20) menyatakan bahwa kewirausahaan merupakan suatu kemampuan dalam hal menciptakan kegiatan usaha. Kemampuan menciptakan memerlukan adanya kreativitas dan inovasi yang terus-menerus untuk menemukan sesuatu yang berbeda dari yang sudah ada sebelumnya. Kreativitas dan inovasi tersebut pada akhirnya mampu memberikan kontribusi bagi masyarakat banyak. Pemahaman lain tentang kewirausahaan dijelaskan oleh Suryana (2003:10) yang menerangkan bahwa istilah kewirausahaan dari terjemahan entrepreneurship, yang dapat diartikan sebagai 'the backbone of economy', yaitu syaraf pusat 
perekonomian atau sebagai 'tailbone of economy', yaitu pengendali perekonomian suatu bangsa (Suharto Wirakusumo, 1997:1). Secara etimologi, kewirausahaan merupakan nilai yang diperlukan untuk memulai suatu usaha (start-up phase) atau suatu proses dalam mengerjakan suatu yang baru (creative) dan sesuatu yang berbeda (innovative).

Berdasarkan pengertian kewirausahaan di atas, dapat disimpulan bahwa kewirausahaan adalah proses seseorang dalam mengunakan, memanfaatkan peluang, menciptakan, dan menerapkan sesuatu berdasarkan dari kemampuan dalam memberikan pelayanan secara maksimal, berinovasi, berkreativitas tinggi dalam upaya untuk memperoleh keuntungan secara efektif dengam menerima resiko yang akan di terimanya serta balas jasa yang akan didapatkan dari pekerjaanya.

\section{Minat Wirausaha}

Pengertian minat wirausaha menurut Santoso (dalam Maman Suryamannim, 2006: 22), adalah gejala psikis untuk memusatkan perhatian dan berbuat sesuatu terhadap wirausaha itu dengan perasaan senang karena membawa manfaat bagi dirinya. Intinya adalah pemusatan perhatian yang disertai rasa senang. Sedangkan Menurut Yanto, minat wirausaha adalah kemampuan untuk memberanikan diri dalam memenuhi kebutuhan hidup serta memecahkan permasalahan hidup, memajukan usaha atau menciptakan usaha baru dengan kekuatan yang ada pada diri sendiri. Hal yang paling utama yaitu sifat keberanian untuk menciptakan usaha baru. Pendapat lain diungkapkan oleh penelitian Aris Subandono (2007: 18) yang menyatakan bahwa wirausaha adalah kecenderungan hati dalam diri subjek untuk tertarik menciptakan suatu usaha yang kemudian mengorganisir, mengatur, menanggung risiko dan mengembangkan usaha yang diciptakannya tersebut. Minat wirausaha berasal dari dalam diri seseorang untuk menciptakan sebuah bidang usaha.

Berdasarkan pendapat diatas maka dapat disimpulkan bahwa minat wirausaha merupakan kemampuan, keinginan dan ketertarikan seseorang yang berasal dari dirinya sendiri untuk menghasilkan, menciptakan dan mengembangkan suatu usaha dan walaupun mengandung resiko. 


\section{Kreativitas dan Inovatif}

Kreativitas merupakan kemampuan seseorang dalam bertindak ataupun berfikir untuk mencari pemecahan dalam sebuah kondisi atau permasalahan dengan cerdas yang dapat membawa hasil yang bermanfaat dan tepat. Sedangkan Inovatif adalah usaha seseorang dalam menggunakan dan memanfaatkan sebuah fikiran atau pemikiran yang baru, kemampuan dalam berimajinasi, baik secra individu dan stimulan yang di sekelilingnya untuk menghasilkan produk atau hasil yang baru untuk dirinya ataupun lingkungannya.

Proses kreatif dan inovatif (Suryana: 2003: 2) yang dapat dilakukan oleh orang-orang yang memiliki jiwa dan sikap kewirausahaan yaitu: (a) Percaya diri (yakin, optimis dan penuh komitmen); (b) Berinisiatif (energik dan percaya diri); (c) Memiliki motif berprestasi (berorientasi hasil dan berwawasan ke depan); (d). Memiliki jiwa kepemimpinan (berani tampil berbeda dan berani mengambil resiko dengan penuh perhitungan); (e) Suka tantangan.

Berdasarkan pendapat diatas maka dapat disimpulkan bahwa seseorang yang memiliki kemampuan untuk memecahkan masalah secara cerdas dengan menghasilkan manfaat yang sesuai dengan yang diharapkan maka seseorang tersebut dianggap memiliki kreativitas tinggi. Sedangkan inovasi adalah usaha yang dilakukan oleh seseorang dalam upaya memecahkan masalah dengan menggunakan pemikiran baru lewat imajinasinya atau daya khayalnya.

3. Etika Wirausaha

Kemampuan seseorang dalam melaksanakan etika dengan benar akan menghasilkan sebuah hubungan yang baik anatara seorang wirausaha dengan pelanggan, pemerintah maupun pihak lainnya yang berkaitan dengan dunia bisnisnya. Menurut Kasmir (2014: 23) etika adalah tata cara berhubungan dengan manusia lainnya. Dimana tata cara tersebut berbeda- beda antara satu dengan lainnya atau beragam bentuk. Hal tersebut terjadi karena banyaknya ragam budaya yang ada dalam kehidupan masyarakat yang berasal dari bebragai wilayah. Tata cara tersebut sangatlah diperlukan dlam kehidupan bermasyarakat agar mampu menjalin hubungan yang harmonis, dan saling menghargai satu dengan lainnya. 
Menurut kasmir (2014: 24) ada beberapa ketentuan etika berwirausaha yang harus dilaksanakan seorang wirausaha dalam rangka upaya untuk menjalankan, memajukan dan membesarkan usahanya dalam waktu yang relatif lebih lama untuk bertahan. Berikut ketentuan yang harus dilaksanakan yaitu: (a) Sikap dan perilaku seorang pengusaha harus mengikuti norma yang berlaku dalam suatu negara atau masyarakat; (b) Penampilan yang ditunjukkan seorang pengusaha harus selalu apik, sopan, terutama dalam menghadapi situsi atau acara-acara tertentu; (c) Cara berpakaian pengusaha juga harus sopan dan sesuai dengan tempat dan waktu yang berlaku; (d) Cara berbicara seorang pengusaha juga mencerminkan usahanya, sopan, penuh tata krama, tidak menyinggung atau mencela orang lain; (e) Gerakgerik seorang pengusaha juga dapat menyenangkan orang lain, hindarkan gerkgerik yang dapat mencurigakan.

Selain ketentuan yang diatur dalam etika wirausaha, maka seorang wirausaha harus menanamkan etika atau norma dalam jiwa dan benaknya. Berikut adalah beberapa yang harus ditanamkan dalam jiwa dan benak seorang wirausaha menurut kasmir (2014: 25):

a) Kejujuran; Seorang pengusaha harus selalu bersikap jujur baik dalam berbicara maupun bertindak.

b) BertanggungJawab; Pengusaha harus bertanggungjawab terhadap segala kegiatan yang dilakukan dalam bidang usahanya. Tanggungjawab tidak hanya terbatas pada kewajiban, tetapi juga kepada seluruh karyawannya, masyarakat dan pemerintah

c) Menepati janji; Pengusaha dituntut untuk selalu menepati janji dan konsisten terhadap apa yang telah dibuat dan disepakati sebelumnya.

d) Disiplin; Pengusaha dituntut untuk selalu disiplin dalam berbagai kegiatan yang berkaitan dengan usahanya.

e) Taat hukum; Pengusaha harus selalu patuh dan menaati hukum yang berlaku, baik yang berkaitan dengan masyarakat ataupun pemerintah.

f) Suka membantu; Pengusaha secara moral harus sanggup membantu berbagai pihak yang memerlukan bantuan. Sikap ringan tangan ini dapat ditunjukkan kepada masyarakat dalam berbagai cara. 
g) Komitmen dan menghormati; Pengusaha harus komitmen dengan apa yang mereka jalankan dan menghargai komitmen dengan pihak lainnya. Pengusaha yang menjunjung komitmen terhadap apa yang telah disepakati akan dihargai oleh berbagai pihak

h) Mengejar prestasi; Pengusaha yang sukses harus selalu berusaha mengejar prestasi setinggi mungkin dengan tujuan agar perusahaannya mampu bertahan dari waktu ke waktu.

\section{METODE}

Sasaran kegiatan ini adalah para pemuda usia produktif Karang Taruna Desa Purwadana Kabupaten Karawang Jawa Barat. Pemilihan dan penetapan sasaran pelatihan ini berdasarkan pertimbangan bahwa pada usia muda Antara 17-30 tahun adalah usia produktif dimana seseorang mempunyai semangat dan tekad yang kuat dalam berkarya dan berusaha. Mengingat anggota karang taruna sebagian bekerja sebagai buruh, sehingga diharapkan setelah mengikuti palatihan ini, semangat untuk berwirausaha akan tumbuh dan mulai memikirkan bagaimana untuk memulai suatu bidang bisnis/usaha. Pada akhirnya juga akan meningkatkan kondisi perekonomian desa setempat.

\section{Langkah-langkah Kegiatan PPM}

Berikut merupakan langkah-langkah yang dilakukan dalam kegiatan pelatihan ini.

1. Tahap Persiapan

Tahap persiapan yang dilakukan meliputi:

a. Survey

Tahap ini merupakan tahap paling awal yang dilakukan, tim pelaksana mengunjungi tempat sasaran dan berdialog langsung dengan warga, karang taruna ataupun pemerintah desa setempat. Hal ini penting dilakukan untuk mengetahui dan memahami kondisi daerah yang akan dijadikan sasaran kegiatan dan juga sebagai pendekatan tim terhadap warga.

b. Pemantapan dan penetuan lokasi dan sasaran 
Tahap ini dilakukan dengan cara berkunjung kembali ke tempat sasaran guna menyampaikan dan mensosialisasikan rencana kegiatan yang akan dilakukan serta melakukan pendaftaran terhadap peserta yang akan mengikuti pelatihan.

c. Penyusunan bahan/materi

Tahap ini meliputi penyusunan modul dan presentasi power point yang akan disampaikan.

d. Persiapan peralatan dan alat peraga

Tahap ini memastikan bahwa peralatan pendukung seperti LCD, spidol, white board dan juga peralatan paraga untuk keperlukan praktek seperti peralatan mekanik, sepeda motor yang akan dijadikan peraga praktek tersedia ketika pelaksanaan pelatihan.

2. Tahap pelaksanaan pelatihan

Tahap pelaksanaan pelatihan dibagi menjadi dua hari pelaksanaan yaitu:

Sesi pertama dijelaskan bagaimana untuk memulai suatu bisnis/usaha dan juga bagaimana mengelola suatu kegiatan bisnis tersebut. Materi-materi yang disampaikan meliputi:

a. Prospektif usaha dan bagaimana memulai

Target: peserta terpacu semangatnya untuk memulai suatu bisnis/usaha apapun.

b. Manajemen keuangan

Target: peserta memahami bagaimana cara pengelolaan unit usaha dari sisi keuangan (modal, cash flow, analisa laba rugi, neraca, dan lain-lain)

C. Strategi pemasaran/promosi

Target: peserta memahami bagaimana cara melakukan strategi pemasaran/promosi yang tepat khususnya untuk usaha jasa servis motor dan dapat diterapkan untuk jenis usaha lain.

d. Manajemen SDM

Target: peserta memahami bagaimana cara pengelolaan unit usaha dari sisi SDM

3. Metode yang digunakan terdiri dari beberapa metode:

a. Metode ceramah 
Metode ceramah adalah metode pembelajaran berupa penyampaian paparan materi dari instruktur/trainer dan peserta sebagai pendengarnya.

b. Metode tanya jawab

Metode tanya jawab sangat penting bagi para peserta pelatihan, baik disaat menerima penjelasan materi ataupun saat sesi praktek. Metode ini memungkinkan peserta menggali pengetahuan sebanyak-banyaknya tentang hal-hal lain yang berhubungan dengan palatihan tetapi tidak tersampaikan oleh tim dosen. Pertanyaan juga bias diajukan dari tim dosen kepada para peserta sebagai bentuk evaluasi terhadap tingkat pemahaman peserta.

\section{HASIL DAN PEMBAHASAN}

Kegiatan Pelatihan Kewirausahaan Karang Taruna Desa Purwadana Kabupaten Karawang dilaksanakan pada tanggal 16 Juni 2017, kegiatan pelatihan ini berjalan dengan lancar dan baik yang diikuti oleh para peserta para remaja di lingkungan Desa Purwadana yang teroganisisr dalam Karang Taruna. Kesan yang disampaikan anggota Karang Taruna secara umum merasa sangat puas dengan kegiatan ini, karena sangat bermanfaat dalam kehidupan sehari-hari dan diharapkan mampu menjadi pendorong/motivasi untuk berwirausaha.

Sementara pesan yang disampaikan anggota karang taruna 90\% mengharapkan kegiatan ini dapat dilaksanakan kembali dengan durasi waktu yang lebih lama. Hasil tersebut di atas menunjukkan bahwa pelatihan kewirausahaan karang taruna desa Purwadana Kabupaten Karawang dapat meningkatkan pengetahuan dan keterampilan anggota karang taruna dalam membaca setiap peluang usaha yang dapat dilaksanakan sesuai dengan hard skill dan soft skill hyang dimiliki.

\section{KESIMPULAN DAN SARAN}

Kegiatan pelatihan ini dapat diselenggarakan dengan baik dan berjalan lancar sesuai dengan rencana kegiatan yang telah disusun meskipun belum semua peserta menguasai manajemen dalam melakukan kewirausahaan secara baik dan materi yang disampaikan. Kegiatan ini mendapat sambutan yang positif dan terlihat 
dari aktifnya peserta dalam mengikuti semua materi yang disampaikan dan terlihat dari antusiasnya pertanyaan yang ditanyakan ketika kegiatan dilakukan. Adanya kegiatan lanjutan yang berupa pelatihan sejnis yang diselanggaran secara periodik, sehingga dapat meningkatkan kemampuan pelaku usaha dalam menangani persaingan global.

\section{DAFTAR PUSTAKA}

Alma, B. 2004. Manajemen Pemasaran dan Pemasaran Jasa, Cetakan Keenam. Bandung: Alfabeta.

Bloom, N.B. 2006. Reliability Centered Maintenance Implementation Made Simple. New York: McGraw Hill, Inc.

Corder, A. 1992. Teknik Manajemen Pemeliharaan. Jakarta: Erlangga.

Handoko, T.H. 1999. Dasar-dasar Manajemen Produksi dan Operasi. Edisi pertama, Yogyakarta: BPFE.

Heizer, J, dan Barry Render. 2001. Operations Management. Preventive Maintenance.

Kasmir. 2014. Kewirausahaan Edisi Revisi Jakarta: Raja Grafindo Persada.

Maman Suryamannim. 2006. Minat Berwirausaha pada Mahasiswa Pendidikan Teknik Elektro. Skripsi. FT-UNS

Subandono, A. 2007. Pengaruh Pembelajaran Life Skill Diklat Kewirausahaan Terhadap Minat Berwirausaha Pada Siswa SMKN 1 Semarang. Skripsi.

Suharto Wirakusumo, 1997. Peranan Perguruan Tinggi dalam Menciptakan Wirausaha-Wirausaha Tangguh. Makalah Seminar. Jatinangor: PIBIIKOPIN.

Suhartono, 1991. Manajemen Perawatan Mesin. Jakarta: Rineka Cipta

Suryana, 2003. Kewirausahaan Pedoman Praktis: Kiat dan Proses Menuju Sukses, Edisi Ketiga, Jakarta: Penerbit Salemba. 